\title{
KEMBALINYA DOKTRIN FUKUDA PADA ERA PEMERINTAHAN YUKIO HATOYAMA: STUDI PERAN JEPANG DI ASIA TENGGARA
}

\author{
Kurnia Alamsyah \\ Universitas 17 Agustus1945 Jakarta. \\ Alamsyahkurnia92@gmail.com
}

\begin{abstract}
This study aims to determine how the Fukuda doctrine underlying Japan's foreign policy in Southeast Asia and the Fukuda doctrine underlying the implementation of foreign policy in Southeast Asia during Yukio Hatoyama. The method used is library research. By examining the form of instrument - an instrument of foreign policy cooperation da Japan in Southeast Asia. Based on the results of the study showed Fukuda

Doctrine which is the rationale for Japanese foreign policy in Asia and the policies underlying the cooperation between Japan and Southeast Asia. With the amount of ODA in

Southeast Asia which reaches $40 \%$ in Indonesia, $11 \%$ in Vietnam and $12 \%$ in the

Philippines with ntotal reach $85 \%$ of total Japanese ODA in Southeast Asia. And the

magnitude of the needs of Japan's energy resources which are largely sourced dar developing countries in Southeast Asia such as Indonesia. And the importance of the Straits of Malacca which is the Japanese energy traffic until today. It can be concluded that the Fukuda doctrine underlying Japan's foreign policy in Southeast Asia .
\end{abstract}

Keyword : Docktrin Fukuda, Yukio Hatoyama

\begin{abstract}
ABSTRAK
Penelitian ini bertujuan untuk menegetahui bagaimana doktrin fukuda mendasari kebijakan luar negeri Jepang di Asia Tenggara dan implementasi doktrin fukuda tersebut mendasari kebijakan luar negeri Jepang di Asia Tenggara pada masa Yukio Hatoyama. Metode penelitian yang digunakan adalah library research. Dengan meneliti instrument- instrument yang berupa kebijakan da kerjasama luar negeri Jepang di Asia Tenggara. Berdasarkan hasil penelitian menunjukkan Doktrin fukuda yang merupakan dasar pemikiran politik luar negeri Jepang di Asia mendasari kebijakan dan kerjasama yang besar antara Jepang dan Asia Tenggara. Dengan besarnya ODA di Asia Tenggara yang mencapai 40\% di Indonesia, $11 \%$ di Vietnam dan 12\% di Filipina dengan ntotal mencapai 85\% total ODA Jepang di Asia Tenggara. Dan besarnya kebutuhan Jepang terhadap sumber daya energy yang sebagian besar bersumber dar Negara-negara berkembang di kawasan Asia Tenggara seperti halnya Indonesia. Dan betapa pentingnya selat Malaka yang merupakan jalur lalu lintas energy Jepang hingga saat ini. Maka dapat disimpulkan bahwa doktrin fukuda mendasari kebijakan luar negeri Jepang di Asia Tenggara.
\end{abstract}

Kata kunci : Docktrin Fukuda, Yukio Hatoyama 


\section{PENDAHULUAN}

Salah satu kawasan yang mempengaruhi Jepang dalam arah kebijakan politik luar negerinya adalah Asia Tenggara, yang merupakan kawasan negara - negara yang sedang berkembang, dimana memiliki sejarah yang panjang dan berkaitan erat dengan kepentingan nasionalnya. Secara umum politik luar negeri Jepang terhadap Asia Tenggara dapat dilihat berdasarkan pemikiran - pemikiran dasar Perdana Menteri Jepang.

Pemikiran-pemikiran dasar tersebut dapat diklasifikasikan ke dalam tiga doktrin utama,yaitu Doktrin Yoshida, Doktrin Fukuda, dan Doktrin Miyazawa, ketiga doktrin inilah yang menentukan dan membentuk hubungan Jepang dan Asia Tenggara. ${ }^{1}$ Perbedaan ketiganya mengalami perubahan sejalan dengan perubahan konteks regional dan internasional yang melingkupi dinamika politik luar negeri Jepang. Politik luar negeri Jepang paska PD II terhadap Asia pada umumnya dan Asia Tenggara khususnya lebih banyak ditentukan oleh kepentingan ekonomi Jepang.

Setelah Perang Dingin berakhir, Jepang masih memiliki hubungan, bahkan mungkin semakin kuat peranan di Asia Tenggara. Pada masa ini, peran Jepang di Asia Tenggara memang masih ada yang berupa hubungan bilateral antar negaranegara Asia Tenggara dalam urusan perdagangan, pertukaran pelajar, bantuan ekonomi, dan lain sebagainya. Namun, hubungan antara Jepang dan Asia Tenggara sebagai sebuah kawasan diperkuat dengan kerjasama yang dibuka saat Jepang menjalin hubungan dengan ASEAN.

Perdana menteri Jepang yang baru sejak 16 September 2009, mempunyai arah pemikiran yang selaras dengan doktrin fukuda, yang lebih cenderung mengedepankan hubungan kepada Asia. Asia Tenggara pada masa kepemimpinan PM Hatoyama merupakan magnet bagi pencapaian kepentingan nasional Jepang. Jepang mendukung adanya integrasi ASEAN yang pada akhirnya akan membawa pengaruh pada integrasi Asia Timur. ${ }^{2}$

\footnotetext{
${ }^{1}$ Igor Dirgantara, Jepang di Asia, http://oseafas.wordpress.com/2010/03/16/jepang-di- asia-tenggara/, diakses 26 Oktober 2012, jam 01.30 WIB

${ }^{2}$ Kompas, 1 November 2009
} 
Secara umum politik luar negeri Jepang terhadap Asia Tenggara dapat dilihat berdasarkan pemikiran-pemikiran dasar Perdana Menteri Jepang. Pemikiranpemikiran dasar tersebut dapat diklasifikasikan ke dalam tiga doktrin utama,yaitu Doktrin Yoshida, Doktrin Fukuda, dan Doktrin Miyazawa. Ketiga doktrin inilah yang menentukan dan membentuk hubungan Jepang dan Asia Tenggara. Perbedaan ketiganya mengalami perubahan sejalan dengan perubahan konteks regional dan internasional yang melingkupi dinamika politik luar negeri Jepang. Politik luar negeri Jepang pada era Hatoyama terhadap Asia pada umumnya dan Asia Tenggara khususnya didasarkan pada doktrin fukuda. Berdasarkan uraian yang telah sedikit dijabarkan pada bagian latar belakang maka yang menjadi rumusan masalah dalam penulisan skripsi ini adalah: Apa yang melatarbelakangi Hatoyama mengangkat kembali doktrin fukuda ? Bagaimanakah Hatoyama mengimplementasikan doktrin fukuda dalam politik luar negerinya ? Apa implikasi dari pelaksanaan doktrin fukuda terhadap negara Asia Tenggara?

\section{PEMBAHASAN}

\section{Politik Luar Negeri Jepang di Asia}

Politik luar negeri Jepang secara gambaran umum terhadap Asia Tenggara dapat ditelaah berdasarkan pemikiran-pemikiran dasar Perdana Menteri Jepang. Pemikiran-pemikiran dasar tersebut dapat diklasifikasikan Ke dalam tiga doktrin utama,yaitu Doktrin Yoshida, Doktrin Fukuda, dan Doktrin Miyazawa. Ketiga doktrin inilah yang menentukan dan membentuk hubungan Jepang dan Asia Tenggara. Perbedaan ketiganya mengalami perubahan sejalan dengan perubahan konteks regional dan internasional yang melingkupi dinamika politik luar negeri Jepang.

Singkatnya, dalam melihat Fukuda Doctrine sebagai kebijakan luar negeri Jepang terhadap negara-negara Asia Tenggara, maka dapat dilihat dari berbagai sisi. Dimulai dari latar belakang sejarah kembali masuknya Jepang ke Asia Tenggara, isi Fukuda Doctrine, serta kejadian- kejadian apa yang melatarbelakangi dikeluarkannya doktrin tersebut, termasuk peristiwa-peristiwa di level internasional, kondisi politik (di level decision maker), dan juga kondisi ekonomi negara Jepang saat itu Pasca- 
Perang Dunia II, Jepang menggunakan bentuk diplomasi ekonomi yang diformulasikan oleh PM Shigeru Yoshida yang secara resmi dijalankan sejak tahun 1957.

Pada saat itu proses kembali masuknya Jepang ke Asia Tenggara menitikberatkan pada aspek perekonomian yang meliputi pembayaran pampasan perang dan juga kebutuhan Jepang akan raw materials dari negara-negara Asia Tenggara. Ekspansi ekonomi dan perdagangannya di awal tahun 1970-an mengembalikan posisi Jepang sebagai kekuatan ekonomi besar dan ini membuat gejolak di dalam negara-negara di Asia Tenggara.

Sejak kekalahan pada Perang Dunia II, Jepang menjalankan kebijakan luar negeri dalam bentuk diplomasi ekonomi yang diformulasikan oleh PM Shigeru Yoshida. Kebijakan tersebut secara resmi dijalankan sejak 1957 dan kemudian menjadi dasar kebijakan Jepang terhadap negara-negara Asia Tenggara, termasuk Indonesia. ${ }^{3}$ Diplomasi ekonomi adalah bentuk peaceful expansion dari ekonomi pasar luar negeri Jepang untuk membangun ekonomi nasionalnya, yang kemudian menjadi modus vivendi dari kebijakan luar negeri negara tersebut.

Tetapi sejak 1977, Yoshida Doctrine digantikan oleh Fukuda Doctrine yang diproklamasikan oleh PM Takeo Fukuda dalam pidatonya di Manila. Doktrin ini dirancang untuk menjadi dasar bahwa kebijakan Jepang lebih diarahkan ke Asia Tenggara dan mendorong agar Jepang memainkan peranan politik yang positif di wilayah ini. ${ }^{4}$ PM Fukuda Takeo berusaha sekali lagi untuk memperluas hubungan politik dengan negara- negara Asia Tenggara saat perayaan ulang tahun ASEAN ke10. Ia lalu mengusung sebuah bentuk kebijakan luar negeri baru dengan mengedepankan unsure heart to heart understanding dengan negara- negara Asia Tenggara, dimana salah satu aspek yang dimunculkan adalah pendekatan budaya.Sejak inilah, kemudian hubungan Jepang- Asia Tenggara dianggap memasuki fase baru.

Politik luar negeri Jepang paska PD II terhadap Asia pada umumnya dan Asia Tenggara khususnya lebih banyak ditentukan oleh kepentingan ekonomi Jepang. Sebab terikat konstitusi Jepang pasal 9 melarang Jepang menjadikan perang

\footnotetext{
${ }^{3}$ Sueo, Sudo, The Fukuda Doctrine: New Dimension in Japanese Foreign Policy. 1992, hal. 2

${ }^{4}$ Ibid, hal. 3-4
} 
sebagai politik luar negerinya.

Di Era Pasca Perang dunia II Jepang mulai mengalirkan bantuan ekonomi ke Asia Tenggara. Disamping upaya Jepang memberikan kompensasi bagi negara bekas jajahannya, Jepang juga menyiapkan Asia Tenggara sebagai salah satu pasar bagi ekspor barang-barang yang diproduksinya. Bantuan yang diberikan kepada negara-negara Asia

Tenggara dengan sendirinya disesuaikan dengan kebutuhan strategi ekspornya. Sebagai misal, Jepang membantu pembangunan transportasi yang diarahkan untuk membantu Asia Tenggara sekaligus memperlancar aliran masuk barang-barang eskpornya.

Sementara itu Indonesia sebagai negara kaya minyak sudah tentu menjadi incaran utama Jepang yang membutuhkan energi dalam jumlah besar bagi industriindustrinya. ${ }^{5}$ Meningkatnya kebutuhan Jepang akan energi, baik minyak maupun gas alam, membuat hubungan Jepang dan Indonesia semakin kuat. Indonesia menjamin kebutuhan energi Jepang dan otomatis mendapatkan lebih banyak bantuan luar negeri di banding negara lain di Asia Tenggara.

\section{Peran Implementasi dan Kebijakan Regional Jepang di Asia Tenggara Peran Jepang di ASEAN}

Hubungan Jepang-ASEAN memasuki babak baru saat Perdana Menteri Takeo Fukuda mendeklarasikan Fukuda Doktrin pada tahun 1977. Kebijakan Fukuda Doktrin menurut Michael Yuhuda merupakan inisiatif pertama Jepang yang paling ambisius setelah berakhirnya Perang Dunia

II. $^{6}$ ASEAN tidak saja ditempatkan sebagai kawasan paling penting bagi Jepang, tetapi juga sebagai "lahan" strategis Jepang untuk memainkan peranannya sebagai pemimpin Asia.

Misi Jepang dalam penyelesaian masalah Indo-China sangat terkait dengan upayanya menjaga ASEAN bebas dari pengaruh komunis dan menciptakan stabilitas

\footnotetext{
${ }^{5}$ Ezra F. Vogel, Japan as Number One In Asia, dalam Gerld E Curtis (ed), The United States, Japan, and Asia : Challenges for US Policy, New York: W.W Norton dan Company, 1994, hal 160

${ }^{6}$ Michael Yuhuda, The International Politics of Asia-Pasific:1945-1955, London: Routledge, 1996, hlm 243.
} 
politik regional. Dengan begitu, Jepang dapat fokus memajukan perekonomiannya yang selama ini membutuhkan ASEAN sebagai sumber bahan mentah industri Jepang, pangsa pasar produk- produk Jepang, tempat investasi, dan jalur perdagangan maritim Jepang.

Dalam salah satu isi Fukuda Doktrin, juga terdapat poin "heart-to- heart understanding". Landasan Jepang mengeluarkan kebijakan ini dilatarbelakangi oleh peristiwa demonstrasi "anti Jepang" saat kunjungan Perdana Menteri Kakuei Tanaka ke negara-negara ASEAN pada tahun 1974. Demonstrasi yang berujung pada kerusuhan ini merupakan bentuk penolakan masyarakat ASEAN atas dominasi perekonomian Jepang di negaranya. Para demonstran menilai Jepang menjajah ASEAN dalam bentuk baru melalui banyaknya aliran modal Jepang yang masuk ke negara-negara Asia Tenggara. Jepang juga dinilai hanya ingin mengeksploitasi kekayaan alam negara-negara Asia tenggara / ASEAN untuk kepentingan industrinya.

\section{Peran Ekonomi dan Perdagangan Jepang di ASEAN}

Dalam kebijakan luar negeri Jepang, dikenal istilah adanya pemisahan antara politik dan ekonomi (seikei-bunri). Seikei-bunri mengandung arti bahwa peran politik Jepang di ASEAN sangat terkait dengan kepentingan ekonomi Jepang. 7 ASEAN selama ini telah dipersiapkan Jepang sebagai kawasan tujuan ekspor, tujuan investasi, dan sumber bahan baku bagi industri Jepang. Semua aspek-aspek tersebut, mendasari Jepang untuk lebih meningkatkan peran ekonominya dalam perdagangan, bantuan pembangunan pemerintah (Official Development Aid /ODA), dan sumber investasi langsung (Foreign Direct Investment /FDI). Ketiga elemen diatas, telah membawa Jepang menjadi salah satu mitra dagang utama bagi ASEAN, sumber terbesar ODA dan sumber FDI.

Hubungan perdagangan antara Jepang dengan negara-negara ASEAN telah berlangsung jauh sebelum ASEAN dibentuk. Adapun yang melatar belakangi hubungan dagang Jepang-ASEAN antara lain: Pertama, untuk memenuhi kebutuhan

\footnotetext{
7 Ana Monica Pop, "Japan ASEAN Relations in the context of Globalization", International Journal of Bussiness Research, 2007, dalam http://findarticles.com/p/articles/mi_6773/is_6_7/ai_n28522947, (diunduh pada tanggal $12 \mathrm{jUNI}$

2013, pukul 02:06 WIB)
} 
bahan mentah dan energi. Sebagai negara yang berbasis industri, Jepang sangat miskin akan sumber daya industrial. Untuk itu, Jepang memerlukan pasokan produkproduk pertambangan yang banyak terdapat di negara-negara ASEAN. Kedua, keinginan Jepang untuk mengembangkan wilayah pemasaran hasil industrinya.

Konsistensi produk-produk Jepang dengan harga terjangkau dan berkualitas tinggi, menjadi daya tarik tersendiri bagi konsumen di negara- negara Asia Tenggara. Meningkatnya upah buruh dan mahalnya biaya produksi domestik menjadi alasan Jepang untuk merelokasi industrinya dan membuka MNC (Multinational Corporation) di sejumlah negara- negara kawasan Asia Tenggara. Tujuannya agar upah buruh dan biaya produksi menjadi lebih murah sehingga produk buatan Jepang semakin kompetitif untuk dipasarkan.

\section{Implementasi dan Implikasi Doktrin Fukuda dalam kebijakan luar negeri Jepang di Asia Tenggara era Yukio Hatoyama}

a. Doktrin fukuda

Selama 20 tahun masa setalah Perang dingin, Jepang mendasari hubungan politiknya pada Asia Tenggara dengan menjaga kerendahan hati. Pada tahun 1974, PM Kakue Tanaka melakukan perjalanan ke kawasan Asia Tenggara untuk melakukan 'tes' keadaan sekaligus memperluas hubungan yang tidak hanya berdasar pertukaran ekonomi semata. ${ }^{8}$

Kemunculan Jepang pada tahun 1970-an sebagai pemain utama dalam ekonomi global memunculkan kekhawatiran di antara negara- negara Asia Tenggara mengenai peran apakah yang akan dimainkan oleh Jepang. Beberapa ketakutan muncul terkait kemunculan Jepang sebagai kekuatan ekonomi raksasa. Ketika PM Jepang Kakue Tanaka mengunjungi Asia Tenggara pada tahun 1974, terdapat gerakan protes antiJepang di Indonesia (peristiwa Malari) dan Thailand. Protes tersebut diarahkan pada penolakan terhadap MNC (perusahaan multinasional) dari Jepang yang dikhawatikan akan mengambil alih pasar lokal. Hal ini selain terkait dengan pengalaman buruk di masa perang, juga

\footnotetext{
${ }^{8}$ Green, Michael J, Japan's Reluctant Realism. New York : Palgrave, 2003
} 
menunjukkan adanya indikasi bahwa Jepang dipandang sebagai kekuatan ekonomi yang eksploitatif. Jepang kemudian berusaha menghapuskan anggapan negatif semacam ini melalui aliran besar program-program bantuan. ${ }^{9}$ Hal ini selain terkait dengan kekacauan-kekacauan anti-Jepang, juga terkait dengan adanya ASEAN Summit di Bali pada bulan Febuari 1976, dimana Jepang tidak diundang. ${ }^{10}$

Pemilihan perdana menteri baru pada bulan Desember 1976, merupakan awal baru dari Politik Luar Negeri Jepang di kawasan Asia Tenggara. Sebagai pemimpin yang dikenal sangat kuat dari kalangan partai LDP atau Liberal Democratic Party yaitu partai mayoritas di Jepang, perdana menteri Takeo Fukuda merupakan perdana menteri yang cukup dikenal memiliki diplomasi yang baik dikalangan negara-negara di wilayah Asia Tenggara. Hal tersebut ditandai dengan beberapa kebijakannya yang banyak berkonsentrasi untuk mempromosikan hubungan diplomasinya di kawasan Asia yang dikenal dengan "Asia-Centered Diplomacy".

Kebijakan luar negeri Fukuda menekankan pada tiga prinsip dasar yaitu; pertama, Jepang akan menjalankan pemerintahannya dengan menggunakan kekuatan ekonomi tanpa kekuatan militer; kedua, Jepang harus bertanggung jawab dan ikut ambil bagian untuk membantu negara- negara Asia dari kebergantungan ekonomi; ketiga, Jepang harus ikut bertanggung jawab dalam upaya menyelesaikan krisis ekonomi yang dihadapi dunia dan memiliki kemampuan untuk memperbaiki keadaan ekonomi dengan menyelesaikan permasalahan dari Korea Selatan. $^{11}$

Aspek penting lain yang dicanangkan oleh perdana menteri Fukuda adalah "budaya". Fukuda memiliki tugas yang cukup berat untuk dapat kembali membuktikan peranannya di kawasan Asia tenggara setelah masa perdana menteri sebelumnya yaitu Yoshida Shigeru. Dengan berbagai perasaan curiga yang diarahkan kepada Jepang akibat dari diplomasi ekonomi yang dicanangkan oleh perdana Menteri sebelumnya akhirnya masih banyak meninggalkan perasaan curiga dari negara-negara Asia terhadap kepentingan Jepang di kawasan Asia.

\footnotetext{
${ }^{9}$ Ibid, hal 183

${ }^{10}$ Matray I, James, Japan's Emergence As A Global Power. Westport : Greenwood, 2001, hal. 98

${ }^{11}$ Sueo Sudo, The International Relations of Japan and South East Asia (Forging A New

Regionalisme), Routledge London, 2002, hal. 36
} 
Untuk menjadikan kebijakan luar negeri dari Fukuda ini berjalan dengan efektif, Fukuda perlu untuk memikirkan cara untuk memberitahukan kebijakan tersebut dengan cara yang tepat dan waktu yang tepat. Keterlibatan Fukuda dengan negara-negara Asia tenggara merupakan sesuatu yang penting, hal tersebut dikarenakan pemimpin dari faksi partai LDP sebelumnya yaitu Nobusuke Kishi telah membuka jalinan yang substansial dengan negara-negara Asia Tenggara melalui upaya pembayaran pampasan Perang.

Semenjak tahun 1972 Fukuda sudah menyuarakan untuk menjalin hubungan baru dengan negara Asia Tenggara melalui hubungan kebudayaan sebagai bentuk perwujudan dari anti militernya Jepang. Dan perlunya menjalin hubungan dengan membangun rasa saling percaya berdasarkan rasa kepercayaan dan pengertian yang lebih baik lagi melalui kebudayaan.

Banyak kalangan yang mengusulkan untuk segera membentuk kebijakan luar negeri Jepang menjadi sebuah doktrin, dilakukan dengan segera. Hal ini dikarenakan para pembuat kebijakan melihat kurangnya minat dan ketertarikan dari negara-negara Asia tenggara terhadap Jepang, yang diakibatkan dari sebuah peristiwa gerakan anti Jepang pada tahun 1974. Dimana gerakan tersebut merupakan sebuah reaksi balik dari diplomasi Jepang sendiri yang pada saat itu berkonsentrasi melalui penguatan ekonomi atau yang dikenal dengan "Strhengthening Economic Power". Yang mengakibatkan dijulukinya Jepang sebagai negara "Economic Animal". Faktor kedua juga dikarenakan setelah berakhirnya perang Vietnam pada tahun 1975, orientasi dari kebijakan luar negeri Jepang selalu mengikuti gaya dari kebijakan Amerika Serikat. Dengan demikian para pembuat kebijakan di era Fukuda berinisiatif untuk menjalin kembali hubungan dengan negara-negara ASEAN dengan diplomasi yang baru.

Dengan begitu lahirlah sebuah prinsip dasar dari kebijakan luar negeri Jepang terhadap negara-negara ASEAN yang terdiri dari tiga prinsip yaitu; Pertama, Jepang menolak kekuatan militer dan berjanji untuk ikut serta berkontribusi terhadap upaya menjaga perdamaian di kawasan ASEAN, kedua, Jepang akan berupaya melakukan yang terbaik untuk menjalin hubungan dan kerjasama dengan rasa percaya diri berdasarkan kepercayaan dari "hati ke hati", ketiga, Jepang akan menjadi partner yang sejajar bagi negara-negara ASEAN dan 
bekerja sama secara positif berdasarkan rasa saling percaya. ${ }^{12}$

Rasa percaya dari "hati ke hati" yang coba diupayakan oleh Fukuda diwujudkan melalui kebudayaan. Melalui pengenalan kebudayaan, Fukuda berharap akan tercipta rasa saling percaya dan mengenal satu sama lain. Fukuda mengatakan bahwa melalui promosi kebudayaan akan dapat mendorong kemajuan ekonomi. Hal ini pun didukung oleh Tsutomu Sugiura Direktur Marubeni Research Intsitute yang menyatakan;

Melalui doktrin Fukuda tersebutlah Jepang dapat menjalin hubungan yang lebih dekat lagi dengan negara-negara ASEAN dengan harapan rasa curiga yang selama ini dikahawatirkan dikit demi sedikit dapat terhapus dan muncul rasa saling percaya.

Joseph S. Nye, dosen ahli politik internasional dari Harvard yang menemukan istilah "Soft Power" di pertengahan tahun 1980-an membahas mengenai budaya pop kontemporer Jepang sebagai sumber "Soft Power" Jepang yang baru. Ia melihat 'soft powere Jepang bukan hanya berasal dari budaya tradisional Jepang seperti Zen, Karate, tetapi juga manga, anime, dan elemen budaya lainnya."Nihon no sofuto pawa: Sono Genkai no Kanosei”

\section{Official Development Asisstance (ODA) dan FDI}

Jepang juga berperan bagi kemajuan perekonomian seluruh dunia dengan cara mempunyai program bantuan ekonomi yang ditujukan kepada negara-negara berkembang. Program ini disebut Official Development Assisstance (ODA) yang meliputi dukungan bagi usaha-usaha mandiri yang dilakukan oleh negara-negara yang sedang berkembang dan diberikan dalam berbagai bentuk, seperti:

1. Bantuan hibah (Grant Aid), yang tidak perlu dibayar kembali, diberikan untuk membantu negara-negara yang sedang berkembang agar dapat memenuhi kebutuhan dasar rakyatnya di bidang-bidang pangan, kesehatan, dan pendidikan.

2. Pinjaman (Yen Loan), pinjaman dana yang menguntungkan karena bunga pinjaman yang sangat rendah, dan masa pengembaliannya yang relativepanjang.

\footnotetext{
${ }^{12}$ Ibid, hal. 36-37.
} 
Bantuan ini biasanya diberikan pada proyek-proyek besar dengantujuan membantu pembangunan ekonomi di sebuah negara, sepertimembangun jembatan dan jalan.

3. Technical Cooperation atau pengiriman warga Jepang dalam kerangkA Japan Overseas Cooperation Volunteers (relawan kerjasama luar negeri Jepang) ke negara-negara yang sedang berkembang untuk berbagi keterampilan dan keahlian mereka di bidang-bidang seperti teknologi, kesehatan, dan pendidikan, kepada rakyat setempat. ${ }^{13}$

ODA secara normatif menurut Larison \& Skidmore (2003) merupakan sebuah kebijakan yang dibuat oleh negara-negar maju untuk membantu negaranegara berkembang dalam proses pembangunannya dengann cara menyisihkan sebagian GNP tahunannya. ${ }^{14}$ Dalam bukunya Alan Rix, memaparkan beberapa motif bantuann secara umum.Motif bantuan secara umum dijelaskan Alan Rix (1993) dalam bukunya adalah: ${ }^{15}$

Pertama, untuk motif kemanusiaan, yaitu dimana suatu negarra memberikan bangtuan luar nnegerinya atas dasar kemanusiaan, yaitu dimana suatu negara memberikan bantuan luar negerinya atas dasar kemanusiaan karena suatu negara terkena bencana alam, ataupun perang. Kedua, untuk citra atau harga diri, yaitu dimana suatu negara menyalurkan bantuannya demi membangun image positif. Ketiga, untuk mengamankan kepentingan national, yaitu dimana suatu negara menyalurkan bantuan luar negeri untuk mengamankan kepentingan nasionalnya baik kepentingan keamanan maupuun kepentingan ekonomi. Keempat, Untuk memeproleh kembali keuntungan dalam hal investasi dan pembukaan pasar negara berkembang.

Bantuan pemerintah Jepang atau yang biasa disebut dengan nama ODA ini merupakan kebijakan Perdana Menteri Hayato Ikeda pada tahun 1960-1964. Dalam bahasa Jepang ODA diartikan sebagai keizai kyouryokuatau kerjasama ekonomi. Artiya Jepang melihat ODA bukan sebagai bantuan tetapi sebagai

\footnotetext{
${ }^{13}$ Kementerian Luar Negeri Jepang, 2004, Menjelajahi Jepang, Tokyo, hal 22

${ }^{14}$ Thomas D. Lairson dan David Skidmore, 2003, Internasional political Economy; The struggle For Power and Wealth ( $3^{\text {rd }}$ ed.). California: Thomson Wadsworth, hal. 162.

${ }^{15}$ Alan Rix, 1993, Japan's Foreign Aid Challenge: Policy Reform and Aid Leadership. London: Routledge, hal.18-19.
} 
kerjasama ekonomi yang sarat dengan kepentingan bisnis dan ekonomi Jepang. Dengan kata lain Jepang menggunakkan ODA sebagai kebijakan luar negerinya dalam mencapai kepentingan nasional.

Kontribusi ODA begitu efektif untuk mempromosikan kepentingan ekonominya dikawasan. Secara perlahan namun pasti , ODA menjadi bagian paling penting dalam kebijakan luar negeri Jepang dan menjadikannya pendonor terbesar didunia. Bantuan luar negeri memungkinkan pemerintah Negara pendonor untuk mempengaruhi perekonomian Negara penerima, selain itu pula bantuan luar negeri dapat menunjang peningkatan investasi asing di Negara berkembang.

Bantuan-bantuan tersebut dilakukan oleh Jepang tidak semata- mata karena motif kemanusiaan atau pun tanggung jawab moral, melainkan bertolak pada kepentingan perekonomiannya. Dapat diketahui dari adanya sifat yang mengikat pada setiap bantuan-bantuannya, yang akhirnya bertujuan pada teknik pemasaran ekspor Jepang. Dengan istilah David Arase pada bukunya Buying Power, ODA Jepang merupakan suatu cara bagi Jepang untuk membeli kekuasaan. ${ }^{16}$ Adapun tujuan dasar disalurkannya ODA Jepang yang ada antara lain: ${ }^{17}$

Pertama, menstimulasikan ekonomi domestik dan ekspor Jepang. Kedua, sebagai cara untuk mengamankan sumber-sumber bahan mentah dan energi bagi keperluan domestik dan industrinya. Ketiga, sebagai alat untuk memperluas pengaruh Jepang atas dinamika ekonomi-politik global ataupun mengintegrasikan wilayah-wilayah tertentu (terutama Asia Pasifik) ke dalam pengaruh Jepang, seperti apa yang dicita-citakan Jepang saat Perang Dunia II (sekalipun kali ini tidak melalui jalur militer).34 Serta keempat, sebagai satusatunya cara untuk bisa berhubungan baik dengan negara-negara berkembang, terutama yang negaranegara yang pernah dijajah oleh Jepang.

Hasegawa juga menyimpulkan bahwa bantuan Jepang, pada dasarnya memiliki dua tujuan besar yakni untuk kepentingan nasional serta dominasi

\footnotetext{
${ }^{16}$ David Arase, Buying Power: Thepolitikal Economy of Japan's Foreign Aid,1995, Lynne Publisher Inc. hal 203-205.

${ }^{17}$ John White, The Politics of Foreign Aid (New York: St. Martin Press, 1974), hlm. 30.
} 
internasional, baik secara ekonomi maupun politik (walaupun secara nonmiliteristik). ${ }^{18}$

Salah satu wilayah regional yang mendapatkan banyak ODA Jepang adalah wilayah Asia Tenggara, terutama pada pasca krisis minyak pada tahun 1970, Jepang cenderung memfokuskan diri pada wilayah Asia. Dengan motif ekonomi yang pada dasarnya menjadi motif utama penyaluran ODA Jepang ke wilayah Asia Tenggara, sekalipun ada motif lainnya seperti motif politik yaitu sebagai bentuk usaha dalam membendung pengaruh komunisme di Negaranegara Asia Tenggara yang merupakan sumber bahan-bahan mentah bagi kegiatan Industri Jepang serta basis komoditas mereka.

Selain menerima bantuan terbesar dari ODA Jepang, ASEAN juga dipersiapkan sebagai kawasan tujuan investasi. Perusahaan-perusahaan Jepang telah menanamkan FDI nya dalam skala besar ke negara-negara ASEAN sejak 1972. Pada tahun 2001, dari total nilai investasi sejumlah 6,8 triliun Yen Jepang di Asia Timur dan Asia Tenggara, 57,1\% nya atau 3,9 triliun Yen berada di ASEAN, dan sisanya sekitar 21,5\% untuk China Daratan. ${ }^{19}$ Pada tahun 20042009, dari total FDI negara-negara di luar ASEAN, Jepang memberikan kontribusi paling besar. Bahkan, FDI Jepang jumlahnya dua kali lipat lebih besar dari FDI AS di ASEAN

Jepang lebih memfokuskan bantuannya hanya kepada negara- negara yang terkait dengan kepentingan perekonomiannya, yaitu negara- negara berkembang yang berada ada di Asia ( khususnya Asia Tenggara dan Timur), yang mana merupakan daerah yang kaya akan bahan-bahan mentah bagi industry Jepang dan merupakan basis pasar bagi ekspornya, jadi terdapat kepentingan perdangan Jepang dalam ODA-nya.

Pelaksanan ODA Jepang terlihat jelas dimana kepentingan politik dan ekonominya tersebut menjadi dasar kebijakann ODA tersebut digelontorkan, yang mana ODA Jepang tersebut menjadi salah satu diplomasi Jepang dalam menerapkan Politik Luar Negerinya.

Indonesia merupakan negara penerima ODA terbesar dari Jepang diantara

\footnotetext{
${ }^{18}$ Sukehiro Hasegawa, Japanese Foreign Aid: Policy and Practice (New York: Praeger, 1975), hlm. v.

${ }^{19}$ Japan Times, “Tokyo-ASEAN Summit Set to Further Relations”, 11 Desember 2003.
} 
negara-negara anggota ASEAN pada 2004-2009, sekitar 45\% aliran ODA yang dikucurkan Jepang kepada Indonesia (dapat dilihat di table 4.2 pada skripsi). Hal tersebut dapat terjadi mengingat pentingnya Indonesia bagi Jepang, yang merupakan yang sangat berpengaruh bagi Jepang, yang tentu saja berkenaan dengan kepentingan nasional Jepang.

\section{KESIMPULAN}

Berdasarkan pembahasan sebelumnya pendahulu, dapat diketahui bahwa doktrin fukuda mendasari kebijakan luar negeri Jepang di Asia Tenggara pada masa pemerintahan Yukio hatoyama, itu dapat terllihat dari besarnya ODA yang di kucurkan Jepang kepada negara-negara di kawasan Asia Tenggara. Seperti halnya bantuann ODA di Indonesia Timor leste dan Vietnam, yang mana pendistribusian ODA tersebut terbesar diantara negara-negara pendonor ODA lainnya.

Selain dari bantuan ODA, doktrin fukuda yang mendasari kebijakan luar negeri Jepang pada masa Hatoyama juga dapat di ketahui dari besarnya kebutuhan Jepang akan sumber ernegy dan sumber bahan baku yang dibutuhkannnya dalam rangka mencapai kepentingan nasionalnya. Seperti yang ditelah dibahas pada bab sebelumnya, bahwa Asia Tenggara merupakan jalur ekspor dan import yang berperan penting bagi Jepang.

Implementasi dari doktrin fukuda dalam kebijakan luar negeri Jepang di Asia tenggara selama kurun waktu 4 dekade berjalan dengan konsisten dan berdamapak positif bagi Jepang maupun negara-negara berkembang di Asia Tenggara, itu dapat terlihat pada saat terjadinya krisis di tahun 1997-1998, dengan didistribusikannya ODA Jepang dan berbagai kerjasama serta investasi antar Jepang dan negara-negara di Kawasan Asia Tenggara dapat membuat Jepang memperoleh timbal balik atas bangkitnya negara-negara berkembang tersebut.

Dan implementasi dari doktrin fukuda dalam kebijakan luar negeri Jepang di Asia Tenggara masih terus efektif hingga pada masa pemerintahan Perdana Menteri Yukio Hayotama, terlihat dengan semakin eksklusifnya kerjasama Jepang dengan organisasi Regional Asia Tenggara yaitu ASEAN. Dan kini semakin banyak bentuk kerja sama dan invetasi serta bantuan ODA yang dilakukan Jepang.

Politik Luar negeri Jepang yang didasari jepang pada era Yukio Hatoyama 
tetap mengangkat doktrin Fukuda, mengingat pentingnya negara-negara di kawasan Asia, khususnya Asia Tenggara yang merupakan sumber bahan baku industry dan sumber energy dalam mendudkung industrinya. Jepang pada Era Yukio Hatoyama tetap menganggap penting kawasan Asia Tenggara yang memang berperan penting bagi kelangsungan bangsanya. Dan hal tersebut jelas berdampak kepada keberlangsungan ekonomi Jepang.

\section{Daftar Pustaka}

Agung Banyu, Anak \& Yanyan Mochamad, 2005, Pengantar Ilmu Hubungan Internasional, PT. Remaja Rosdakarya, Bandung.

Arase, David. 1995. Buying power : the political economy of Japan's foreign aid Lynne Rienner Publishers.

Bruce M. Koppel and Robert M. Orr, Jr., eds., 1993.Japan's Foreign Aid: Power and Policy in a New Era. Boulder, CO: Westview Press,

Burchill, Scot dan Andrew Linklater. (Terjemahan oleh M. Sobirin) 2009. Teori-teori Hubungan innternasional. Bandung: Nusa Media.

Couloumbis, Theodore A. dan James H. Wolve. (Terjemahan oleh Mercedes Marbun) 1990. Pengantar Hubungan Internasional: Keadilan dan Power. Bandung: Abardian.

Dasuki, Achmad dan Rochiati Wiraatmadja. 1976. Sejarah Asia Timur. Bandung: IKIP.

Hasegawa, Sukehiro. 1975. Japanese Foreign Aid: Policy and Practice. New York: Praeger

Holsti, K.J.1987, Politik Internasional Suatu Kerangka Analisis, Bina Cipta, Bandung Keempat

Inoguchi, Takashi. Japan Goes Regional, Japan's Asian Policy : Revival and Response, Takashi Inoguchi 9 (Ed), New York : Palgrave Macmillan, 2002.

Irsan, Abdul. 2007. Budaya dan Perilaku : Politik Jepang di Asia. Jakarta : Grafindo Khazanah ilmu.

Kedutaan Besar Jepang, 1989, Jepang Sebuah Pedoman Saku, Foreign Press Center, Japan.

Kevin, Cooney. 2007. Japan's Foreign Policy Since 1945. New York : East Gate Book Lapian, A.B. 197 Kolonialisme di Asia Tenggara. Jakarta: LIPI .

Michael J, Green. 2003. Japan's Reluctant Realism. New York : Palgrave, 2003. Mas 'oed, Mohtar (1990). Ilmu Hubungan Internasional : Disiplin dan Mdetodologi. Jakarta ; LP3ES.

Morgenthau, Hans J. (terjemahan oleh S. Maimoen, A.M Fatwan, Cecep Sudrajat)2010. Politik Antar Bangsa. Jakarta: Yayasan Pustaka Obor, Edisi Revisi - Cetakan Pertama. 
Nasrun, Mappa. 1990, Indonesia Relations With The South Pacific Countries; Prospect and Problems, UNHAS, Makassar

Nester, William R. 1 Japan's Foreign Aid: Power and Policy in a New Era.Boulder, CO: Westview Press, 1997

Nurhayati, Yeti 1987. Langkah-langkah Awal Modernisasi Jepang. Jakarta: Dian Rakyat.

Riri Dwianto, Kerjasama Keamanan di Asia Timur, Dalam Bantarto Bandoro (ed) Agenda dan Penataan Keamanan di Asia Pasifik, Jakarta, CSIS, 1996Sakamoto, Taro,1982. Jepang : Dulu dan Sekarang, Jakarta: Yayasan Obor Indonesia.

Soebantardjo. 1958. Sari Sedjarah Asia-Australia. Jogjakarta: Bopkri.

Soebantardjo. 1958. Sari Sedjarah; Jilid 1: Asia-Australia. Yogyakarta: Bopkri Suradjaja, I Ketut.1984. Pergerakan Demokrasi Jepang. Jakarta: Karya Unipress.

Sudo, Sueo. 1992. The Fukuda Doctrine: New Dimension in Japanese Foreign Policy.

Vogel, F. 1994. Japan as Number One In Asia, dalam Gerld E Curtis (ed), The United States, Japan, and Asia : Challenges for US Policy, New York :W.W Norton dan Company.

Yukichi, Fukuzawa, 1985. Jepang di Antara Feodalisme dan Modernisme. Jakarta: Pantja Simpati.

Yuhuda, Michael, The International Politics of Asia-Pasific:1945-1955, London: Routledge.

\section{Lain-lain}

Ana Monica Pop, "Japan ASEAN Relations in the context of Globalization”,International Journal of Bussiness Research, 2007

Dennis D. Trinidad, “Japan's ODA at The Crossroads: Disbursement Patterns of Japan's Development Assistance To Southeast Asia", dalam Jurnal Asia Perspective, Vol. 31, No. 2, 2007, dari www.asianperspective.org/articles/v31n2-e.pdf, pada tanggal 10 July 2013, pukul 14.20 WIB.

Dra. Hj. Ani khoirunnisa, M.Si. 2001. “Teori hubungan Internasional (Bagian Pertama)”. Diktat Jurusan Ilmu Hubungan Internasional, FISIP, Universita 17 Agustus 194 Jakarta.

Igor Dirgantara, Jepang di Asia, http://oseafas.wordpress.com/2010/03/16/jepang-diasia-tenggara/,

http://id.wikipedia.org/wiki/Pemberontakan_Satsuma.

http://dikasaurus29.blogspot.com/2013/06/restorasi-meiji-jepang.html, http://oseafas.wordpress.com/2010/03/16/jepang-di-asia-tenggara/ 